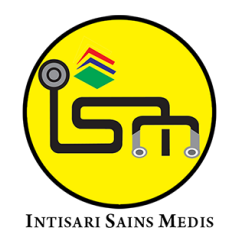

Published by Intisari Sains Medis

\title{
Diagnosis dan tatalaksana rinosinusitis maksilaris odontogenik yang meluas sampai etmoid dan frontal: laporan kasus
}

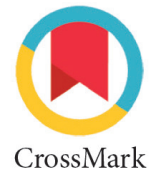

CrossMark

\author{
Agus Santosa ${ }^{1{ }^{*}}$, Nyoman Dian Permata Sari ${ }^{1,2}$, Ida Bagus Semara Putra ${ }^{1,2}$, \\ Dewa Ayu Putu Sri Masyeni ${ }^{3}$
}

\begin{abstract}
Background: Sinusitis is an inflammatory process in the nasal mucosa, especially in the paranasal sinuses. Sinusitis problems are important and need special attention in cases of sinusitis that do not improve after being given conventional therapy. The purpose of this paper is to establish the diagnosis and management of odontogenic maxillary rhinosinusitis that extends to the ethmoid and frontal areas.

Case presentation: A male patient, aged 22 years, came to the ENT clinic at Mangusada Hospital, Badung. Based on the history, physical examination, supporting examination in the form of CT-scan so

that it was diagnosed as chronic rhinosinusitis et causa odontogenic which extends to the ethmoid and frontal. The treatment chosen was surgery in the form of Functional Endoscopic Sinus Surgery (FESS) and septorhinoplasty because in this case the patient had complications and did not respond to medical therapy. Postoperative evaluation, complaints of smelly mucus, nasal congestion and headache were not felt.

Conclusion: The diagnosis of chronic rhinosinusitis et causa odontogenic which extends to the ethmoid and frontal based on CT-Scan and the treatment given to the patient in the form of FESS and septorhinoplasty.
\end{abstract}

Keywords: Functional Endoscopic Sinus Surgery (FESS); Maxillary rhinosinusitis, Odontogenic, Septorhinoplasty. Cite This Article: Santosa, A., Sari, N.D.P., Putra, I.B.S., Masyeni, D.A.P.S. 2021. Diagnosis dan tatalaksana rinosinusitis maksilaris odontogenik yang meluas sampai etmoid dan frontal: laporan kasus. Intisari Sains Medis 12(3): 812-816. DOl: 10.15562/ism.v12i3.1171

'Departemen Ilmu Kesehatan Telinga Hidung Tenggorok-Bedah Kepala dan Leher, Fakultas Kedokteran, Universitas Warmadewa, Denpasar, Bali, Indonesia;

${ }^{2}$ Departemen IImu Kesehatan Telinga Hidung Tenggorok-Bedah Kepala dan Leher Rumah Sakit Umum Daerah Mangusada, Badung, Bali, Indonesia; ${ }^{3}$ Departemen IImu Penyakit Dalam, Fakultas Kedokteran, Universitas Warmadewa, Denpasar, Bali, Indonesia;

\footnotetext{
*Korespondensi:

Agus Santosa;

Departemen Ilmu Kesehatan Telinga Hidung Tenggorok-Bedah Kepala dan Leher, Fakultas Kedokteran, Universitas Warmadewa, Denpasar, Bali, Indonesia;

omangbabe@gmail.com
}

Diterima: 12-09-2021

Disetujui: $30-10-2021$

Diterbitkan: 04-11-2021

\section{ABSTRAK}

Latar belakang: Sinusitis merupakan proses inflamasi pada mukosa hidung, lebih khususnya pada sinus paranasal. Masalah sinusitis menjadi penting dan perlu perhatian khusus pada kasus sinusitis yang tidak membaik setelah diberikan terapi konvensional. Tujuan penulisan ini adalah untuk menegakkan diagnosis dan penatalaksan rinosinusitis maksilaris odontogenik yang meluas sampai etmoid dan frontal.

Presentasi kasus: Seorang pasien laki-laki, berusia 22 tahun datang ke poli THT RS Mangusada, Badung. Berdasarkan anamnesis, pemeriksaan fisik, pemeriksaan penunjang berupa (T-scan sehingga didiagnosis sebagai rinosinusitis kronis et causa

odontogenic yang meluas sampai etmoid dan frontal. Penatalaksanaan yang dipilih adalah pembedahan berupa Functional Endoscopic Sinus Surgery (FESS) dan septorhinoplasti, karena pada kasus ini pasien mengalami komplikasi dan tidak memberikan respon dengan terapi medikamentosa. Evaluasi pasca operasi, keluhan ingus berbau, hidung tersumbat dan nyeri kepala sudah tidak dirasakan.

Kesimpulan: Diagnosis rinosinusitis kronis et causa odontogenic yang meluas sampai etmoid dan frontal berdasarkan dari CT-Scan dan tatalaksana yang diberikan pada pasien berupa FESS dan septorhinoplasti.

Kata kunci: Functional Endoscopic Sinus Surgery (FESS); Odontogenik; Rhinosinusitis maksilaris, Septorhinoplasty. Sitasi Artikel ini: Santosa, A., Sari, N.D.P., Putra, I.B.S., Masyeni, D.A.P.S. 2021. Diagnosis dan tatalaksana rinosinusitis maksilaris odontogenik yang meluas sampai etmoid dan frontal: laporan kasus. Intisari Sains Medis 12(3): 812-816. DOl: 10.15562/ism.v12i3.1171 


\section{PENDAHULUAN}

Sinusitis merupakan kejadian inflamasi pada bagian mukosa hidung dan melibatkan sinus paranasalis. Sinusitis juga adalah salah satu masalah kesehatan yang cukup sering mengalami peningkatan kasus dalam dekade belakangan ini, dan berdampak bagi pengeluaran finansial masyarakat.1,2 Penyakit sinusitis dibagi menjadi kelompok akut dan kronik. Apabila dilihat dari ilmu anatomi, sinus maksilaris terletak di antara bagian tengah hidung dan rongga mulut. Lokasi ini termasuk bagian yang berisiko tinggi terhadap invasi patogen, hal ini dikarenakan jalurnya melewati ostium sinus maupun rongga mulut. ${ }^{3,4} \mathrm{Di}$ samping iu, kondisi lesi periapikal dan penyakit periodontal yang juga dilaporkan menyebabkan penebalan mukosa pada sinus maksilaris sekitar $58-78 \%{ }^{5}$

Merujuk pada data Departemen Kesehatan (Depkes) RI (2003), melaporkan kejadian penyakit hidung dan sinus sekitar 102.817 penderita rawat jalan di rumah sakit, dan berada dalam urutan ke- 25 dari 50 pola penyakit peringkat utama. ${ }^{6}$ Selain itu, studi oleh Farhat di Departemen THT- KL/RSUP H. Adam Malik, menunjukan angka insiden penyakit sinusitis odontogenic sebesar $13,7 \%$ kasus dan mayoritas terjadi akibat abses apikal dengan presentase $71,4 \%$ kasus. ${ }^{4}$

Kondisi akut dari sinusitis maksilaris dapat disebabkan oleh beberapa kondisi seperti faringitis akut, rhinitis akut, tonsillitis akut, adenoiditis, infeksi gigi rahang atas P1, P2, serta Ml, M2, M3 (odontogenic). ${ }^{5}$ Penyebab yang perlu diwapadai adalah kejadian sinusitis oleh odontogenic. Sinusitis odontogenic pada dasarnya merupakan sinusitis maksilaris, khususnya sinus maksila terdapat akar gigi pada prosesus alveolaris di rahang atas. Sehingga, pada bagian rongga sinus maksila dipisahkan hanya oleh tulang yang tipis dengan akar gigi rahang bagian atas. Pada beberapa kondisi kadang tidak ditemukan adanya tulang pembatas. Hal ini akan terjadi terutama adanya infeksi gigi pada rahang atas atau inflamasi jaringan periodontal yang mudah untuk terjadinya penyebaran patogen secara langsung ke sinus atau dapat juga melalui pembuluh darah dan limfe., ${ }^{4,7}$ Oleh karena itu, pentingnya diagnosis dan tatalaksana dari sinusitis maksilaris perlu dibijaksanai agar hasil yang diperoleh dapat meningkatkan kualitas hidup pasien.

Dengan demikian, tujuan penyusunan laporan kasus ini adalah untuk mengetahui diagnosis dan penatalaksanaan rinosinusitis maksilaris odontogenik yang meluas sampai etmoid dan frontal.

\section{LAPORAN KASUS}

Seorang pasien laki-laki berusia 22 tahun datang ke Poli Telinga Hidung Tenggorokan (THT) Rumah Sakit Umum Mangusada, Badung dengan keluhan keluar ingus dari hidung kiri berwarna kekuningan dan berbau busuk sejak dua bulan yang lalu. Keluhan dirasakan terusmenerus dan tidak kunjung membaik. Keluhan disertai dengan nyeri tumpul pada pipi kiri dan rasa penuh pada wajah. Pasien juga mengeluhkan sakit kepala dan hidung tersumbat terutama pada pagi hari.

Enam bulan sebelumnya pasien mengeluh sakit gigi pada gigi geraham

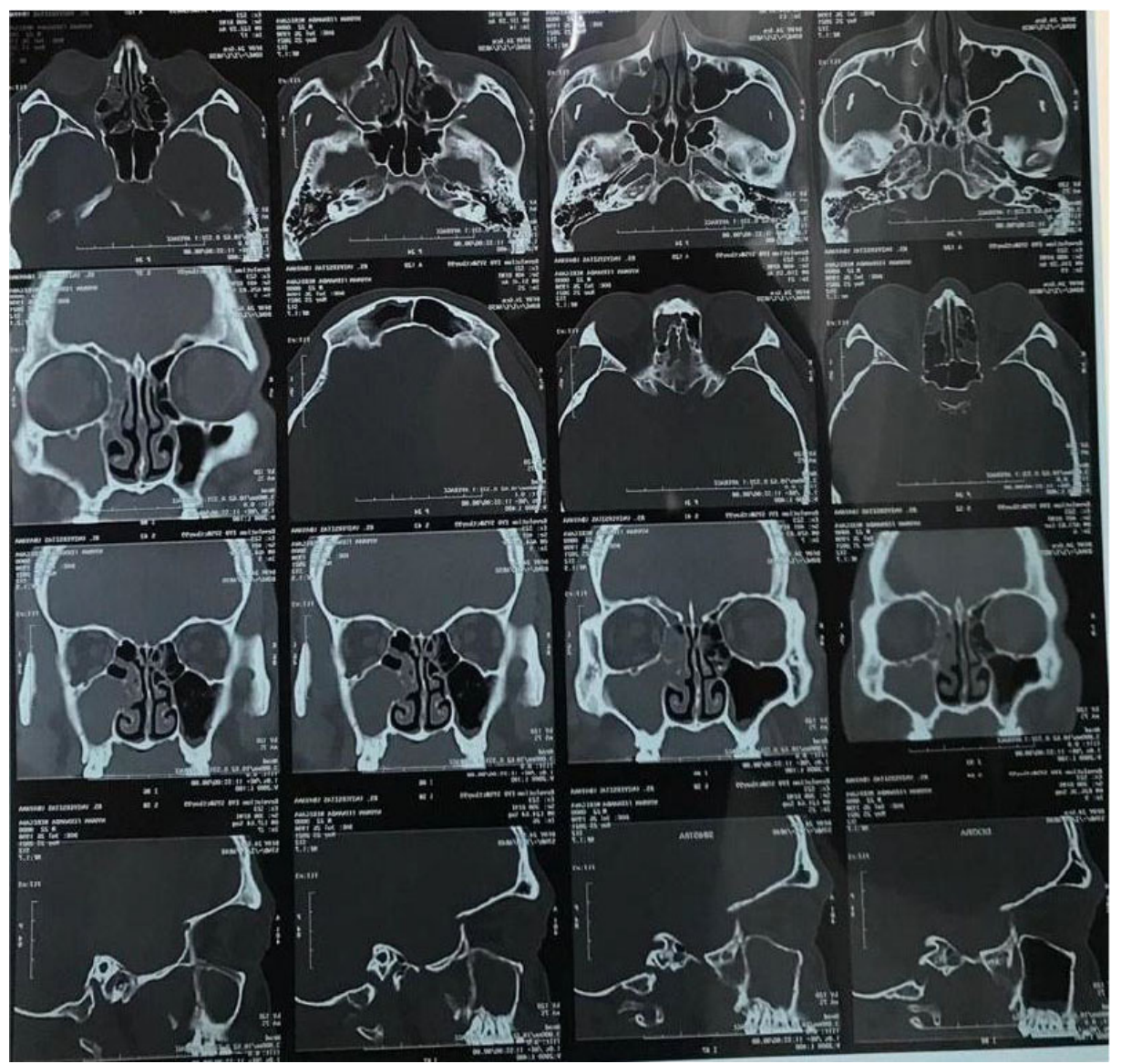

Gambar 1. Hasil pemeriksaan CT-scan. bagian kiri atas. Pasien memiliki riwayat gigi berlubang pada gigi geraham sebelah kiri atas sejak tiga bulan yang lalu. Pasien telah melakukan pencabutan gigi di dokter gigi.

Pasien mengaku sebelumnya tidak kemasukan benda asing ke dalam hidungnya. Tidak ada riwayat pilek dan bersin-bersin sebelumnya. Riwayat demam disangkal. Riwayat batuk dan pilek berulang disangkal. Pasien pernah mengkonsumsi obat warung untuk meredakan sakit giginya, tapi belum pernah melakukan pengobatan untuk mengatasi keluhan saat ini. Pasien mengaku tidak mengkonsumsi obat dalam jangka waktu panjang. Pasien juga mengaku di keluarga tidak ada yang mengalami keluhan yang serupa seperti pasien.

Setelah dilakukan anamnesis, selanjutnya dilakukan pemeriksaan fisik. Pada pemeriksaan fisik didapatkan keadaan umum tampak sakit ringan, kesadaran compos mentis, tekanan darah 130/80 mmHg, nadi $88 \mathrm{x} /$ menit, 
pernapasan $20 \mathrm{x} /$ menit, suhu $36,7^{\circ} \mathrm{C}$. Pada pemeriksaan hidung luar didapatkan nyeri tekan pada hidung sinistra dan nyeri tekan sinus maksilaris sinistra. Pada pemeriksaan rhinoskopi anterior didapatkan mukosa cavum nasi sinistra hiperemis, konka media sinistra sulit dinilai dan didapatkan edem, sekret dan hipertrofi pada konka inferior sinistra.

Pada pemeriksaan penunjang, dilakukan CT-Scan sinus dan didapatkan gambaran edema mukosa dan cairan dalam sinus maksilaris, etmoidalis, spenoidalis, frontal serta deviasi septum nasi, seperti ditunjukan pada Gambar 1.

Berdasarkan anamnesis, pemeriksaan fisik, pemeriksaan penunjang pasien di diagnosis dengan rinosinusitis kronis et causa odontogenic. Penatalaksanaan yang dipilih adalah pembedahan berupa Functional Endoscopic Sinus Surgery (FESS) dan septorhinoplasti, karena pada kasus ini pasien mengalami komplikasi dan tidak memberikan respon dengan terapi medikamentosa.

Evaluasi pasca operasi, keluhan ingus berbau, hidung tersumbat dan nyeri kepala sudah tidak dirasakan.

\section{DISKUSI}

Sinusitis mengacu pada kriteria yang dikeluarkan oleh European Position Paper on Rhinosinusitis and Nasal Polyps (EP3OS) tahun 2007, merupakan terjadinya inflamasi mukosa hidung dan pada sinus paranasal, pada kodisi ini juga disertai dua atau lebih gejala seperti adanya dirasakan hidung tersumbat atau adanya nasal discharge ditambah nyeri pada fasial, serta penurunan indra penciuman pada pasien. Sinusitis dibagi menjadi dua menurut waktunya, yaitu sinusitis akut dan sinusitis kronik. Sinusitis akut bila keluhan terjadi kurang dari 12 minggu dan sinusitis kronis bila keluhan terjadi 12 minggu atau lebih. ${ }^{1,6,7}$

Berdasarkan pasien didapatkan keluhan keluar cairan berupa ingus dari hidung kiri dengan warna yang kekuningan disertai dengan bau busuk, disertai nyeri tumpul pada pipi kiri dan rasa penuh pada wajah. Hal ini sesuai gejala pada sinusitis maksilaris. Pada sinusitis maksilaris, terdapat gejala lokal maupun gejala sistemik. Adapun gejala lokal yang dapat ditemui yaitu terdapat ingus kental pada hidung yang kadang berbau busuk dan juga dirasakan ingus seperti mengalir ke nasofaring. Selain itu, gejala seperti hidung yang tersumbat dan seringkali terdapat nyeri tumpul atu seperti menusuk khas pada pipi, serta nyeri di tempat lain (referred pain). Ditemukan juga sekret mukopurulen yang keluar dari hidung dan kadang-kadang memiliki bau yang tidak enak. Gejala lain seperti penciuman terganggu dan ada perasaan penuh dipipi waktu membungkuk ke depan. Perasaan sakit kepala juga kadang dialami pada waktu bangun tidur dan dapat membaik sewaktu-waktu. Untuk gejala sistemik pada umumnya demam dan lemas. ${ }^{8-10}$

Sinus maksila dikenal juga dengan istilah antrum high more. Bagian sinus ini sering mengalami kejadian infeksi. Hal ini disebabkan setidaknya oleh empat factor yaitu; a) Sinus paranasal terbesar; b) Letak ostiumnya lebih tinggi dari dasar, sehingga aliran sekret atau drainase dari sinus maksila hanya tergantung dari gerakan silia; c) Dasar sinus maksila adalah dasar akar gigi (prosesus alveolaris), sehingga infeksi gigi dapat menyebabkan sinusitis maksilaris; d) ostium sinus maksila terletak di meatus medius, disekitar hiatus semilunaris yang sempit, sehingga mudah tersumbat. ${ }^{11,12}$

Kesehatan pada bagian sinus sangat dipengaruhi oleh patensi ostium sinus dan lancarnya aliran keluar dari mukosiliar di dalam kompleks osteomeatal. Sinus dilapisi oleh sel epitel respiratorius. ${ }^{13-15}$ Lapisan mukosa yang melapisi sinus dapat dibagi menjadi dua yaitu lapisan viscous superficial dan lapisan serous profunda. Cairan mukus dilepaskan oleh sel epitel untuk membunuh bakteri maka bersifat sebagai antimikroba serta mengandungi zat- zat yang berfungsi sebagai mekanisme pertahanan tubuh terhadap kuman yang masuk bersama udara pernafasan. Cairan mukus secara alami menuju ke ostium untuk dikeluarkan jika jumlahnya berlebihan. ${ }^{8,16}$ Faktor yang paling penting yang mempengaru hipatogenesis terjadinya sinusitis yaitu apakah terjadi obstruksi dari ostium. ${ }^{17}$ Jika terjadi obstruksi ostium sinus akan menyebabkan terjadinya hipooksigenasi, yang menyebabkan fungsi silia berkurang dan epitel sel mensekresikan cairan mukus dengan kualitas yang kurang baik.
Disfungsi silia ini akan menyebabkan retensi mukus yang kurang baik pada sinus., ${ }^{4,17-19}$

Kondisi sinusitis maksilaris ini dapat disebabkan akibat infeksi gigi rahang atas yang terjadi karena infeksi bakteri anaerob pada karies profunda sehingga jaringan lunak gigi dan sekitarnya rusak..$^{18-20}$ Pada saat kondisi terbukanya pulpa, bakteri lebih mudah untuk menginfeksi sehingga membentuk gangren pulpa. Kondisi ini meluas yang menyebabkan selaput periodontium terinfeksi sehingga menjadi periodontitis serta terbentuknya pus. ${ }^{21-23}$ Kemudian, tahap selanjutnya menjadi abses periodontal yang meluas dan mencapai tulang alveolar sehingga terjadi abses pada bagian alveolar. Abses yang terbentuk pada tulang alveolar akan mempengaruhi dasar sinus maksila sehingga memicu proses inflamasi pada sinus tersebut. Kondisi perkembangan ini akan diperburuk oleh adanya disfungsi silia, obstruksi ostium sinus dan abnormalitas sekresi mukus sehingga akumulasi cairan pus dalam sinus penuh dan menyebabkan terjadinya sinusitis maksilaris. ${ }^{24}$

Pasien pada kasus mengaku mengalami sakit gigi karena gigi berlubang pada graham kiri atas tiga bulan yang lalu. Pada kasus dicurigai terdapat karies yang menyebabkan timbulnya keluhan pada pasien sesuai dengan pernyataan di atas, maka dapat disimpulkan pada penyebab sinusitis maksilaris pada pasien ini adalah karena odontogenic. Sinusitis berdasarkan waktunya dibagi atas sinusitis akut dan kronik. Sinusitis akut bila gejala berlangsung kurang dari 12 minggu, dan dikatakan sinusitis kronik bila gejala berlangsung 12 minggu atau lebih. ${ }^{1,25}$ Pada kasus, pasien mengaku keluhan mulai timbul sejak enam bulan, maka dapat disimpulkan pasien mengalami sinusitis maksilaris kronik et causa odontogenic.

Pada pemeriksaan fisik sinus maksilaris dapat dilakukan inspeksi dan palpasi. Pada inspeksi, pemeriksaan yang diperhatikan adalah adanya pembengkakan pada muka. Palpasi didapatkan nyeri tekan pada pipi yang sakit. Pemeriksan rinoskopi anterior dapat melihat kelainan rongga hidung yang berkaitan dengan sinusitis seperti udemkonka, hiperemi, sekret (nasal drip), krusta, deviasi septum, tumor atau polip. ${ }^{9}$ 
Pada kasus, saat palpasi didapatkan adanya nyeri tekan pada hidung dan pipi sebelah kiri. Pada kasus pemeriksaan rhinoskopi anterior didapatkan mukosa cavum nasi sinistra hiperemis, konka media sinistra sulit dinilai dan didapatkan edem, sekret dan hipertrofi pada konka inferior sinistra yang diakibatkan proses inflamasi.

Pada pemeriksaan penunjang, dilakukan CT-Scan sinus dan didapatkan gambaran edema mukosa dan cairan dalam sinus maksilaris, etmoidalis, spenoidalis, frontal serta deviasi septum nasi. Berdasarkan pada Husni, bahwa indikasi pemeriksaan CT-scan pada pasien dengan rhinosinusitis kronis ditujukan untuk evaluasi lebih lanjut jika dalam tatalaksana medikamentosa tidak memberi hasil yang diinginkan. Kondisi khusus yang terjadi pada sinus maupun kompleks ostiomeatal akan terlihat lebih baik melalui CT-Scan. ${ }^{24}$

Berdasarkan anamnesis, pemeriksaan fisik, pemeriksaan penunjang pasien di diagnosis dengan rinosinusitis kronis et causa odontogenic yang meluas sampai etmoid dan frontal. Penatalaksanaan yang dipilih adalah pembedahan FESS dan septorhinoplasty, karena pada kasus ini pasien mengalami komplikasi dan tidak memberikan respon dengan terapi medikamentosa.

Functional endoscopic sinus surgery diperkenalkan di Amerika Serikat pada tahun 1985 oleh David Kennedy dan bertahun-tahun sebelumnya di Eropa oleh Messenklinger dan Stammberger. ${ }^{25}$ Dengan teknik ini, wilayah anatomis yang sempit dari kompleks ostiomeatal dapat divisualisasikan dan didekati secara akurat melalui pembedahan dan focus dalam mengobati penyebab yang mendasarinya. Tehnik FESS umumnya dilakukan pada pasien rinosinusitis kronis yang gagal dalam manajemen medis. Tujuan FESS adalah untuk meningkatkan pembersihan mukosiliar dan ventilasi dengan menghilangkan jaringan penyakit obstruktif dan FESS diperkirakan dapat meningkatkan penghantaran obat. Kompleks ostiomeatal merupakan daerah penting dalam fungsi sinus ethmoid anterior, frontal, dan maksila. ${ }^{25}$ Sebuah Studi oleh Thakur dkk., ${ }^{26}$ menunjukan bahwa pasien yang menjalani septoplasti dengan FESS telah menunjukkan perbaikan baik pada VAS maupun radiologis dibandingkan dengan pasien yang menjalani FESS saja. Penelitian ini juga menyimpulkan kondisi deviasi septum nasal sebagai faktor etiologi utama dalam rhinosinusitis maksilaris kronis dan menyoroti pentingnya septoplasti pada hasil akhirnya. ${ }^{26}$

\section{SIMPULAN}

Pasien laki-laki dengan usia 22 tahun datang ke poli THT RSUD Mangusada, Badung dengan keluhan keluar ingus dari hidung kiri berwarna kekuningan dan berbau busuk sejak dua bulan yang lalu. Berdasarkan anamnesis, pemeriksaan fisik, pemeriksaan penunjang pasien didiagnosis dengan rinosinusitis kronis et causa odontogenic yang meluas sampai etmoid dan frontal. Penatalaksanaan yang dipilih adalah FESS dan septorhinoplasti, karena pada kasus ini pasien mengalami komplikasi dan tidak memberikan respon dengan terapi medikamentosa. Evaluasi pasca operasi, keluhan ingus berbau, hidung tersumbat dan nyeri kepala sudah tidak dirasakan.

\section{ETIKA PENELITIAN}

Pasien telah setuju informed consent dan foto hasil pemeriksaan setuju untuk dipublikasikan serta sesuai pedoman COPE dan ICMJE.

\section{KONFLIK KEPENTINGAN}

Penulis menyatakan tidak terdapat konflik kepentingan dalam penulisan laporan kasus ini.

\section{PENDANAAN}

Penulisan dalam laporan ini murni pendanaan penulis pribadi tanpa adanya dukungan hibah baik dari negara atupun pihak swasta.

\section{KONTRIBUSI PENULIS}

Seluruh penulis memiliki kontribusi yang sama dalam penyusunan laporan kasus ini baik dari perencanaan, pencarian data pasien, analisis data pasien, dan penyusunan naskah publikasi.

\section{DAFTAR PUSTAKA}

1. Drake RL, Mitchell WM. Gray's The Anatomical Basis of Clinical Practice. 41st Edition: Elsevier, 2015. 9780702071645.

2. Dhingra PL, Dhingra S. Diseases of Ear, Nose and Throat-eBook. Elsevier India; 2017.

3. Flint PW, Haughey BH, Robbins KT, Thomas JR, Niparko JK, Lund VJ, et al. Cummings otolaryngology-head and neck surgery e-book. Elsevier Health Sciences; 2014.

4. Chang CC, Incaudo GA, Gershwin ME, editors. Diseases of the sinuses: a comprehensive textbook of diagnosis and treatment. Springer; 2014.

5. Kwah JH, Somani SN, Stevens WW, Kern RC, Smith SS, Welch KC, Conley DB, Tan BK, Grammer LC, Yang A, Schleimer RP. Clinical factors associated with acute exacerbations of chronic rhinosinusitis. Journal of Allergy and Clinical Immunology. 2020;145(6):1598-605.

6. Indriany S, Munir D, Murni AY, Adnan A, Yunita R, Sarumpaet S. Proporsi karakteristik penderita rinosinusitis kronis dengan kultur jamur positif. Medan: ORLI, 2016; 46(1):26-33.

7. Kaper NM, Aarts MC, van Benthem PP, van der Heijden GJ. Otolaryngologists adhere to evidence-based guidelines for chronic rhinosinusitis. European Archives of OtoRhino-Laryngology. 2019;276(4):1101-8.

8. Antunes MB, Gudis DA, Cohen NA. Epithelium, cilia, and mucus: their importance in chronic rhinosinusitis. Immunol Allergy Clin N Am. 2009;29:631-43.

9. Cottrell J, Yip J, Chan Y, Chin CJ, Damji A, de Almeida JR, et al. Quality indicators for the diagnosis and management of chronic rhinosinusitis. International forum of allergy \& rhinology. 2018;8(12):1369-79.

10. Rezeki S, Alibasyah ZM, Saputri D. Gambaran Status Periodontal Pada Pasien Sinusitis (Kajian Di Poliklinik THT Rumah Sakit Umum Meuraxa). Journal Of Syiah Kuala Dentistry Society. 2019;4(2):26-31.

11. Soepardi EA, Iskandar N, Bashiruddin J, Restuti RD. Buku Ajar Ilmu Kesehatan Telinga Hidung Tenggorok Kepala \& Leher Edisi 7. Jakarta: Fakultas Kedokteran Universitas Indonesia. 2012.

12. Montone KT. Pathology of fungal rhinosinusitis: a review. Head and neck pathology. 2016;10(1):40-6.

13. Douglas R, Bruhn M, Tan LW, Ooi E, Psaltis A, Wormald PJ. Response of peripheral blood lymphocytes to fungal extracts and staphylococcal superantigen $\mathrm{B}$ in chronic rhinosinusitis. The Laryngoscope. 2007;117(3):411-4.

14. Orlandi RR, Marple BF, Georgelas A, Durtschi $\mathrm{D}$, Barr L. Immunologic response to fungus is not universally associated with rhinosinusitis. Otolaryngology-Head and Neck Surgery. 2009;141(6):750-6.

15. Shin SH, Lee YH, Jeon CH. Proteasedependent activation of nasal polyp epithelial cells by airborne fungi leads to migration of eosinophils and neutrophils. Acta Otolaryngol. 2006;126:1286-94. 
16. Kaplan A. Canadian guidelines for chronic rhinosinusitis: clinical summary. Canadian Family Physician. 2013;59(12):1275-81.

17. Bachert C, Pawankar R, Zhang L, Bunnag C, Fokkens WJ, Hamilos DL, et al. ICON: chronic rhinosinusitis. World Allergy Organization Journal. 2014;7(1):1-28.

18. Veronica E, Suyantari SA, Swari WD, Purwaningrum NM, Sudarsa PS. Effectiveness of Antibacterial Extract of Kenop (Gomphrena Globosa) Flower Extract Against Growth of Propionibacterium Acne Bacteria. Indonesian Journal for Health Sciences. 2020;4(2):115-20.

19. Wang X, Moylan B, Leopold DA, Kim J, Rubenstein RC, Togias A, et al. Mutation in the gene responsible for cystic fibrosis and predisposition to chronic rhinosinusitis in the general population. JAMA. 2000;284:1814-9.

20. Antunes MB, Gudis DA, Cohen NA. Epithelium, cilia, and mucus: their importance in chronic rhinosinusitis. Immunol Allergy Clin N Am. 2009;29:631-43.

21. Moore P, Blakley B, Meen E. Clinical predictors of chronic rhinosinusitis: do the Canadian clinical practice guidelines for acute and chronic rhinosinusitis predict CT-confirmation of disease? Journal of Otolaryngology-Head \& Neck Surgery. 2017;46(1):1-4.

22. Huang Z, Ma J, Sun Y, Zhou B. Maximal medical therapy for chronic rhinosinusitis: a survey of Chinese otolaryngologists. Ear, Nose \& Throat Journal. 2020;99(3):159-64.

23. Sukato DC, Abramowitz JM, Boruk M, Goldstein NA, Rosenfeld RM. Endoscopic sinus surgery improves sleep quality in chronic rhinosinusitis: a systematic review and metaanalysis. Otolaryngology-Head and Neck Surgery. 2018;158(2):249-56.

24. Husni, TR. Diagnosis dan Penanganan Rinosinusitis. Universitas Unisyah. 2020:212-
29. Avialable from: http://conference.unsyiah. ac.id/TIFK/1/paper/viewFile/783/78.

25. Wofford MR, Kimbell JS, Frank DO, Dhandha V, McKinney KA, Fleischman GM, Ebert CS, Zanation AM, Senior BA. A computational study of functional endoscopic sinus surgery and maxillary sinus drug delivery. Rhinology. 2015;53(1):41.

26. Thakur K, Gupta VD, Surya M, Ahluwalia A. Comparative evaluation of FESS and septoplasty with FESS in cases of DNS with chronic maxillary sinusitis. International Journal of Research in Medical Sciences. 2017;5(8):35239.

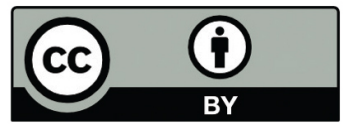

This work is licensed under a Creative Commons Attribution 